\title{
EL SISTEMA PARA LA ADMINISTRACIÓN DE LA COOPERACIÓN INTERNACIONAL EN COSTA RICA*
}

\author{
HERNÁN SOLANO MURILLO \\ División de Fiscalización Operativa y Evaluativa \\ Contraloría General de la República de Costa Rica \\ hernan.solano@cgr.go.cr
}

\section{RESUMEN}

Existe la presunción, entre administradores públicos, formadores de opinión y la ciudadanía, de que las irregularidades producidas en los últimos años en el manejo de proyectos financiados en el sector público costarricense con recursos de cooperación internacional, han sido consecuencia de vacíos en el marco normativo que sustenta el sistema para la administración de esa cooperación. La investigación procura dilucidar si existe fundamento fáctico para esa presunción; su enfoque, cualitativo, se centró en la comprensión de diversos elementos como: marco jurídico, actores institucionales, competencias y procesos más relevantes, presentes en la actividad de cooperación, así como, en el estudio de evidencia empírica disponible. El estudio concluye que no hay elementos que apoyen que la introducción de reformas en el marco normativo que rige dicha cooperación en Costa Rica, pueda resultar un medio efectivo para modificar ciertas prácticas calificadas como deficientes o irregulares; la evidencia sugiere que en la explicación de dichas deficiencias de gestión, el factor humano ha venido teniendo un mayor peso que las posibles debilidades en el diseño normativo.

* El autor elaboró una síntesis con una parte de los resultados a los que arribó la presente investigación, los que fueron incluidos con carácter institucional por la Contraloría General de la República, dentro del capítulo de Opiniones y Sugestiones para el mejor manejo de los fondos públicos, de la Memoria Anual del año 2009, publicada el $1^{\circ}$ de mayo de 2010.
PALABRAS CLAVE: COOPERACIÓN INTERNACIONAL, RELACIONES INTERNACIONALES, POLÍTICAS PÚBLICAS.

\section{ABSTRACT}

There is a presumption among public administrators, opinion makers and the public, that irregularities found in recent years in the management of projects funded in the Costa Rican public sector with resources from international cooperation have been the result of gaps in the regulatory framework that supports the management system for such cooperation. Whether there is a factual basis for that assumption is determined through a qualitative research methodology and through the analysis of various elements such as: legal framework, institutional actors, relevant skills and processes related to cooperative activity, and the study of empirical available evidence. It is concluded that there is no evidence to support that the implementation of reforms in the regulatory framework governing such cooperation in Costa Rica is an effective way to modify certain practices considered deficient or irregular; the evidence suggests that the human factor has been a much more important variable than any weakness in policy design as an explanation for the deficiencies in management.

KEYWORDS: INTERNATIONAL COOPERATION, INTERNATIONAL RELATIONS, PUBLIC POLICIES.

\section{INTRODUCCIÓN}

El manejo que el Estado costarricense ha efectuado de la actividad de cooperación internacional fue colocado, a lo largo del segundo semestre de 
2008, en la palestra de discusión política y mediática. Uno de los ejes de debate giró en torno a si una serie de presuntas irregularidades en el manejo de algunos recursos provenientes de dicha cooperación, resultaban o no consecuencia de un marco normativo deficiente e incompleto para regular estas actividades de cooperación.

La presente investigación aspira a reducir un grado importante de opacidad que prevalece en relación con el tema debatido. Para ello, pretende esclarecer si existe apoyo fáctico que sustente la presunción de que las debilidades del sistema de cooperación internacional, resultan en mayor grado atribuibles al conjunto de normas que rigen la actividad de cooperación; ello, por medio del análisis de la composición actual del sistema de administración de la cooperación internacional, con especial énfasis en el examen del marco jurídico, los actores institucionales, las competencias y los procesos más relevantes que se encuentran presentes en esa actividad, así como, mediante el estudio de la evidencia empírica disponible en torno al tema.

\section{Justificación del estudio}

Durante décadas, Costa Rica se ha caracterizado por ser un país receptor de flujos significativos de recursos que provienen de la cooperación internacional, los cuales han venido a apoyar la gestión gubernamental. Los datos más recientes que maneja el Ministerio de Planificación Nacional y Política Económica (MIDEPLAN), indican que durante el período 2000-2005, el país habría recibido un total de US\$3.354,6 millones por este concepto, lo cual equivale, en promedio, a un 3,2\% del Producto Interno Bruto de esos años (MIDEPLAN, 2007a).

Los asuntos relacionados con la cooperación internacional recibida por diferentes instituciones del Estado, ha resultado un tema de sumo interés y de una amplia cobertura mediática; ésta última, se ha visto acrecentada por una discusión muy activa entre los diferentes partidos políticos, los que se han dado a la tarea de hacer que el manejo de estos recursos de cooperación, se torne en un asunto propio del control político $y$, en consecuencia, de interés nacional, lo que ha terminado por permear de forma importante las opiniones que la ciudadanía construye con respecto a la gestión de dichos recursos.

Este tema reviste suma importancia, por cuanto estamos frente a la utilización de recursos que, con prescindencia de la naturaleza que se les otorgue o de los medios que se empleen para su gestión, en definitiva se transforman en bienes y servicios que deben destinarse a finalidades públicas.

\section{Problema de investigación}

A inicios del segundo semestre de 2008, los medios de difusión masiva informaron sobre presuntas irregularidades en el manejo de los proyectos "Asistencia técnica para el fortalecimiento del liderazgo y los procesos de toma de decisiones" y "Gobernabilidad y reforma del Estado como herramientas para el desarrollo", que tuvieron como órgano ejecutor al Ministerio de la Presidencia y se financiaron con recursos de cooperación internacional aportados por el Banco Centroamericano de Integración Económica (BCIE); asimismo, para esas fechas se informó acerca de supuestas irregularidades en el manejo de los fondos destinados al proyecto "Mejoramiento barrial y gestión de programas sociales innovativos", el cual obtuvo financiamiento mediante fondos de cooperación donados por la República de China (Taiwán) y que fuera ejecutado por medio de un contrato de fideicomiso suscrito por esa República como fideicomitente, el BCIE en calidad de fiduciario y el Ministerio de Vivienda y Asentamientos Humanos (MIVAH) como fideicomisario.

Entre otros aspectos de interés, dicha situación derivó en una discusión y en la toma de posi- 
ciones, por parte de políticos, jerarcas públicos, medios de difusión masiva y formadores de opinión -planteadas en algunos casos de manera explícita y en otros de forma insinuada-, con respecto a si las deficiencias e irregularidades que se han producido en el manejo de algunos de los recursos provenientes de la cooperación internacional, tienen su origen en debilidades y vacíos en el marco normativo que sustenta el sistema para la administración de dicha cooperación. No obstante, las discusiones y las posiciones consecuentemente adoptadas, según se recogen en los artículos de opinión y entrevistas en medios de difusión masiva, no se encuentran apoyadas directamente en evidencia empírica ni en un análisis sistemático (Gallardo, R., 2008, 16 de julio; Gallardo, R., 2008, 24 de julio; González, A., 2008, 27 de agosto; Guardia, J., 2008, 8 de julio; Guardia, J., 2008, 22 de julio; Guardia, J., 2008, 29 de julio; Hernández, R., 2008, 21 de agosto; La Nación, 2008, 6 de julio; La Nación, 2008, 24 de octubre; Radio Universidad, 2008, 30 de julio; Rojas, E., 2008, 26 de julio; Sobrado, M., 2008, 13 de julio; Telenoticias, 2008, 4 de julio).

La presente investigación se inscribe en la necesidad de dilucidar, mediante un abordaje analítico, si existe fundamento fáctico que sustente la presunción de que efectivamente las falencias del marco normativo vienen a explicar tales deficiencias e irregularidades. Por lo tanto, su enfoque es de carácter cualitativo, mediante la comprensión de diversos elementos que componen el fenómeno de estudio.

\section{Objeto del estudio}

El objeto de la presente investigación es el sistema vigente en Costa Rica para la administración de la cooperación internacional, ya sea la que se canaliza directamente hacia entes y órganos que componen el sector público, como la que se canaliza por medio de mecanismos de administración alternativos pero que reúne la condi- ción de encontrarse dirigida, en último término, al cumplimiento de objetivos y a la satisfacción de necesidades públicas.

\section{Objetivos de la investigación}

La presente investigación se ha trazado los siguientes objetivos:

- Identificar y sistematizar las similitudes y diferencias que se presentan entre las diversas modalidades de cooperación internacional existentes en Costa Rica, en cuanto al sistema diseñado para administrar dicha cooperación. Para los efectos de la investigación, el sistema de administración para la cooperación internacional, estaría comprendiendo un conjunto de componentes formales relevantes que interactúan dentro de él: actores institucionales, atribuciones y competencias, procesos y actividades.

- Precisar la viabilidad jurídica y el grado de efectividad de que, mediante la introducción de reformas en el marco normativo que rige la cooperación internacional en Costa Rica, se modifiquen ciertas prácticas, calificadas como deficientes o irregulares, que se han venido presentando en la gestión de algunas cooperaciones internacionales.

- Brindar un conjunto de elementos de juicio que sirvan de apoyo a la Contraloría General de la República, para el ejercicio de sus atribuciones y facultades constitucionales y legales de fiscalización de los fondos públicos.

\section{Marco conceptual, referencial y situacional}

El Decreto Ejecutivo n. ${ }^{\circ}$ 35056-PLAN-RE del 12 de noviembre de 2008, en su artículo 2 define la cooperación internacional como el: "Conjunto de acciones de carácter internacional orientadas al intercambio de experiencias y recursos entre países 
desarrollados así como entre estos últimos, para alcanzar metas comunes de desarrollo basadas en criterios de solidaridad, equidad, eficacia, interés mutuo y sostenibilidad".

La cooperación internacional es un componente de las relaciones internacionales, por medio del cual se comparten conocimientos y experiencias acumuladas y se transfieren recursos financieros, orientados normalmente a la atención de problemas y carencias, así como a la promoción y fortalecimiento de diversos ámbitos del desarrollo humano (sociales, ambientales, económicos, culturales, políticos, institucionales, entre otros).

En el contexto de dichas relaciones internacionales, una parte muy significativa de la cooperación internacional es otorgada por Gobiernos y organismos internacionales de desarrollo, acudiendo a canales oficiales y es aquí en donde los Estados -ya sea los otorgantes como los receptores de los recursos- armonizan sus objetivos en materia de cooperación con sus políticas públicas, las cuales pueden definirse como:

Cursos de acción y flujos de información relacionados con un objetivo público definido en forma democrática; los que son desarrollados por el sector públicos y, frecuentemente, con la participación de la comunidad y el sector privado. Una política pública de calidad incluirá orientaciones o contenidos, instrumentos o mecanismos, definiciones o modificaciones institucionales, y la previsión de sus resultados (Lahera, 2002, pp. 15-16).

Ahora bien, aun cuando el Estado conserva para sí el papel más preponderante en los procesos de formulación, ejecución y evaluación de las políticas públicas, no se encuentra solo, sino que lo acompañan diversos agentes que intervienen de una u otra forma en dichos procesos, tales como: organizaciones políticas, medios de comunicación, sector académico, formadores de opinión, grupos de presión y de interés y la ciudadanía en general. Como bien señala Lahera (2002):

...las posibilidades de acción del Estado incluyen las de regular, contribuir a generar externalidades y a lograr masas críticas. También la de entregar información y señales a una comunidad cada vez mejor informada y responsable de sus propias acciones... La integración de los esfuerzos estatales y privados para servir algún fin público -con objetivos bien definidos y reglas del juego claras y estables- lleva a resultados superiores, tanto desde un punto de vista cuantitativo como cualitativo, ya que permite aumentar la participación y la transparencia (pp. 21-22).

Es justamente de la interacción entre los referidos actores y participantes, de donde surgen los espacios de discusión y de toma de posiciones, a los que se aludió al describir el problema de investigación que sustenta el presente documento.

La cooperación internacional suele dividirse en cooperación reembolsable y cooperación no reembolsable. La primera de ellas comprende los préstamos adquiridos por los países en condiciones blandas o concesionales y se le conoce también como cooperación financiera reembolsable. Por su parte, la cooperación no reembolsable se divide en cooperación técnica y cooperación financiera no reembolsable; la primera comprende asesoramiento, capacitación, servicio de voluntariado y la denominada cooperación técnica entre países en desarrollo (CTPD), mientras que la segunda consiste en los recursos que se otorgan en forma de donaciones, sean, en transferencias de dinero que no requieren reembolso (MIDEPLAN, 2007a). Para el caso costarricense, los mecanismos para la administración de recursos de cooperación internacional comportan desde el manejo de los recursos mediante el Sistema de caja única del Estado, pasando por recursos administrados por 
los mismos donantes, fideicomisos (públicos y privados), recursos administrados por parte de organismos internacionales y convenios de financiación específica (MIDEPLAN, 2007a).

MIDEPLAN, en su calidad de órgano de la administración pública con el mayor número de atribuciones y competencias en materia de cooperación internacional, la Procuraduría General de la República, como órgano técnico-consultivo en materia jurídica para sector público, así como la Contraloría General de la República, con potestades y atribuciones para pronunciarse con carácter vinculante en los ámbitos relacionados con la Hacienda Pública, todos ellos han emitido documentos que tratan sobre la cooperación internacional. No obstante, tales documentos no abordan, en ninguno de los casos, el ligamen que pueda existir entre las deficiencias en la gestión de la cooperación y el estado del ordenamiento jurídico en esa materia.

En el ámbito académico nacional, las investigaciones en torno a la cooperación internacional han abordado el tema, mayoritariamente, desde la perspectiva de las relaciones internacionales, así como su vínculo con la formulación y ejecución de políticas, ya sean de alcance nacional, o bien, sectorial e institucional.

En cuanto a las políticas de alcance nacional, Ramírez y Sánchez (1995) aportan un análisis conceptual sobre la política exterior y la cooperación internacional, que incluye la política exterior contemporánea de Costa Rica y su vinculación con la afluencia de recursos externos; asimismo, examinan los principales objetivos de la política exterior costarricense durante la primera Administración Arias Sánchez (1986-1990) y brindan una diagnosis de la cooperación internacional durante ese período. En lo que resulta de mayor interés para el presente ensayo, se efectúa un recuento del marco jurídico institucional de la cooperación Internacional en Costa Rica, que se encontraba vigente al momento en que se realizó esa investigación.

Con respecto al alcance sectorial e institucional, Cordero (1986) reúne en un solo documento la información general sobre los principales organismos de las Naciones Unidas (que incluye: antecedentes, estructura, objetivos y funciones, actividades o áreas de trabajo, programas especiales en algunos casos, financiación del organismo en otros casos, y las formas o mecanismos de cooperación), para que sirva como una guía o directorio de los organismos de cooperación que son fuentes potenciales de cooperación internacional, y que pueda ser objeto de consulta por parte de las instituciones nacionales responsables de la ciencia y la tecnología. Masís (1988) analiza la relación entre la cooperación internacional y el desarrollo eléctrico de Costa Rica, con un marcado énfasis en los proyectos de generación de energía eléctrica ejecutados por el Instituto Costarricense de Electricidad (ICE) y financiados por los Bancos de Desarrollo, todo ello bajo una metodología de estudio de carácter histórico-descriptivo.

Por su parte, el énfasis que el presente estudio pone en los componentes jurídicos y en el análisis de casos concretos de gestión de la cooperación internacional, le hacen diferir en cuanto a sus objetivos y enfoque, respecto de las citadas investigaciones.

\section{METODOLOGÍA}

La presente investigación es de carácter cualitativo y se sustenta en investigación bibliográfica; asimismo, comprende un análisis de la normativa jurídica y técnica vigente en nuestro país, organizada según modalidad de cooperación (técnica, financiera-reembolsable y no reembolsable- y cooperación financiera compuesta por fondos privados), que incluye, entre otras normas relevantes: Constitución Política, Ley de Administración Financiera de la República y Pre- 
supuestos Públicos n. ${ }^{\circ} 8131$ y Reglamento a la Ley de la Administración Financiera de la República y Presupuestos Públicos, Decreto Ejecutivo n. 32988-H-MP-PLAN, Ley Orgánica de la Contraloría General de la República n. ${ }^{\circ} 7428$, Ley de Planificación Nacional n. 5525 y Reglamento General del Ministerio de Planificación Nacional y Política Económica (MIDEPLAN), Decreto Ejecutivo n. ${ }^{\circ}$ 23323-PLAN, Ley de Contratos de Financiamiento Externo con Bancos Privados Extranjeros n. 7010, Ley Orgánica del Banco Central de Costa Rica n. ${ }^{\circ}$ 7558; además, se apoyará en la jurisprudencia constitucional (Sala Constitucional de la Corte Suprema de Justicia) y en la jurisprudencia administrativa más relevante que la Procuraduría General y Contraloría General la República han producido en torno al tema.

\section{El sistema}

\section{Marco jurídico, actores institucionales y competencias}

Costa Rica no cuenta con una ley en vigencia que esté dedicada en forma específica a regular el tema de la cooperación internacional. De ahí que las normas que establecen las atribuciones y competencias de los actores institucionales que participan en la consecución, la concertación, la ejecución, el control, la evaluación y la rendición de cuentas relativos a dicha cooperación, se encuentran diseminadas en algunas leyes y decretos ejecutivos.

a) Normas que rigen la cooperación técnica

En cuanto a la cooperación técnica, las principales responsabilidades del proceso recaen en MIDEPLAN y en el Ministerio de Relaciones Exteriores y Culto (MRREE). De conformidad con el artículo 11 de la Ley de Planificación Nacional, n. ${ }^{\circ}$ 5525, a MIDEPLAN le compete formular, negociar, coordinar, aprobar y evaluar los programas de asistencia técnica, velando por su coherencia con los objetivos del Plan Nacional de DesarroIlo; además, el artículo 14 inciso a) del Reglamento General de MIDEPLAN, Decreto Ejecutivo n. ${ }^{\circ}$ 23323-PLAN y sus reformas, establece que ningún Ministerio ni organismo autónomo o semiautónomo puede iniciar trámites para obtener cooperación internacional, sin la autorización previa de MIDEPLAN. EL artículo 11 de la Ley n. 5525 señala que el MRREE es el canal oficial para transmitir las solicitudes de asistencia técnica, las que deben ser congruentes con la política exterior del país.

Dado su carácter no dinerario, esta modalidad de cooperación no encontrará una expresión monetaria en los presupuestos institucionales de las entidades receptoras de la cooperación; ahora bien, se puede señalar que entre la normativa que le resulta aplicable se encuentran la Ley de Administración Financiera de la República y Presupuestos Públicos (LAFRPP) n. ${ }^{\circ} 8131$, y su Reglamento, Decreto Ejecutivo n. $32988-H-M P-P L A N$, que establecen que el Plan Nacional de Desarrollo (PND) constituirá el marco global que orientará los planes operativos institucionales anuales, así como los de mediano y de largo plazo, lo que implica la incorporación de objetivos, acciones, indicadores y metas para aquellos programas, subprogramas y proyectos que se desarrollarán a partir de la cooperación recibida; concordantemente, las entidades receptoras de la cooperación están Ilamadas también a preparar los informes en los que se consigne el grado de cumplimiento de metas, objetivos, prioridades y acciones estratégicas del PND.

b) Normativa que cobija la cooperación financiera La cooperación financiera puede provenir de empréstitos (cooperación reembolsable) o de donaciones (cooperación no reembolsable), y en tanto los recursos que la constituyan se encuentren catalogados como 
fondos públicos, existe todo un marco legal de competencias de autorización y de controles previos y posteriores que está integrado, entre otras, por la siguiente normativa:

- La Constitución Política, en cuanto a la aprobación legislativa de los convenios internacionales y de los empréstitos o convenios similares que se relacionan con el crédito público, celebrados por el Poder Ejecutivo, según su artículo 121 inciso 15 y lo que sobre este particular señala la Sala Constitucional (1990), así como, en lo conducente, el artículo 140 incisos 10 y 12 referentes, en su orden, a los deberes y atribuciones de Poder Ejecutivo para celebrar convenios, tratados públicos y concordatos, promulgarlos y ejecutarlos una vez aprobados por la Asamblea Legislativa, cuando dicha aprobación la exija la Constitución, así como a la dirección de las relaciones internacionales de la República'. Asimismo, normas relativas al Presupuesto de la República; rendición de cuentas por parte de los funcionarios públicos; deberes y atribuciones de la Contraloría General y de la Tesorería Nacional.

- $\quad$ La Ley de Planificación Nacional n. 5525 en sus artículos 10 y 11 y el Reglamento General del Ministerio de Planificación Nacional y Política Económica (MIDEPLAN) en su artículo 14 inciso a), en cuanto a las autorizaciones emitidas por parte de MIDEPLAN, tanto de previo a que las entidades públicas inicien los trámites para obtener cooperación internacional, como antes de iniciar gestiones

1. Valga señalar que la existencia de un conjunto importante de requisitos y condiciones exigidos por la normativa vigente, para el trámite de cooperación reembolsable en forma de empréstitos -con la participación de diversos entes y órganos públicos- a nuestro juicio ofrece un campo bastante fértil para el despliegue del control político y para una apropiada valoración técnica y financiera de los programas y proyectos que serán financiados con esos recursos. para obtener créditos externos; aprobación final, por parte de ese Ministerio, de los proyectos de cooperación internacional, así como de los proyectos de inversión de los organismos públicos, cuando estos últimos incluyan total o parcialmente financiamiento externo o requieren aval del Estado para su financiación.

- La Ley de Administración Financiera de la República y Presupuestos Públicos y su Reglamento, en lo tocante a la sujeción de los planes institucionales y de los programas de inversión pública, al Plan Nacional de Desarrollo (PND); sistema de Caja Única del Estado (artículo 66); subsistema de crédito público (artículo 81); procesos de emisión y de evaluación de los informes de resultados de la ejecución del presupuesto de las entidades públicas, así como del cumplimiento de metas, objetivos, prioridades y acciones estratégicas del PND. En cuanto a este último aspecto, la Procuraduría General de la República (2003a) se ha referido al ámbito de aplicación, a los diversos entes y órganos públicos, de las normas de la LAFRPP referidas al sometimiento de esos entes y órganos al PND, y sobre la evaluación de resultados, estimándose de interés lo que a ese respecto se señala en punto a las universidades estatales, la Caja Costarricense de Seguro Social, los bancos del Estado y las municipalidades.

- La Ley Orgánica de la Contraloría General de la República n. ${ }^{\circ} 7428$, en lo que respecta a la fiscalización de la Hacienda Pública y de los fondos públicos (recursos, valores, bienes y derechos propiedad del Estado, de órganos, de empresas o de entes públicos), así como de los beneficios patrimoniales que las entidades públicas otorgan a sujetos privados; control presupuestario; aprobación de contratos y convenios; potestades de investigación y de realización de auditorías. 
- La Ley de Contratos de Financiamiento Externo con Bancos Privados Extranjeros n. ${ }^{\circ}$ 7010, en lo referido a la obligación de las instituciones del sector descentralizado y empresas públicas, de obtener la autorización previa del proyecto emitida por MIDEPLAN, el dictamen favorable del Banco Central y la autorización de la Autoridad Presupuestaria, como condiciones indispensables para contratar créditos internos y externos². Asimismo, la Ley Orgánica del Banco Central de Costa Rica n. 7558 establece los deberes y atribuciones del Instituto emisor en materia de política crediticia de la República; además, la emisión de un dictamen por parte de ese Banco, de previo a la realización de trámites efectuados por el Ministerio de Hacienda y por las instituciones públicas, para la consecución de créditos.

c) Cooperación destinada a inversiones públicas Cuando los fondos de cooperación se encuentran destinados a la realización de inversiones públicas, MIDEPLAN debe velar porque los programas de inversión pública -incluidos los de las instituciones descentralizadas- que se financien con estos fondos - de naturaleza pública o privada, reembolsables o no reembolsables- sean compatibles con el orden de prioridad establecido en el PND. A ese Ministerio le han sido otorgadas, en ese ámbito de actuación, algunas competencias y funciones relacionadas con la asignación, ejecución y evaluación de fondos o proyectos especiales de preinversión o financiamiento para el desarrollo, así como de proyectos de Inversión Pública. Por su parte, a la Autoridad Presupuestaria le co-

2. Ahora bien, de conformidad con el artículo 166 inciso a) de Ley Orgánica del Banco Central de Costa Rica, n. ${ }^{\circ}$ 7558, las autorizaciones de parte de MIDEPLAN y de la Autoridad Presupuestaria, que contempla el artículo 7 de la Ley n. ${ }^{\circ} 7010$, no son exigibles a los bancos del Estado. rresponde formular las directrices y los lineamientos generales y específicos de política presupuestaria para los entes y órganos públicos, que incluyen, entre otros, lo relativo a inversión y endeudamiento, así como velar por su cumplimiento. Este marco de actuación está recogido en el Artículo 9 de la Ley n. 5525 y artículos 11 y 12 de su Reglamento; asimismo, en el artículo 21 de la LAFRPP y artículo 13 y siguientes del Reglamento a esta última Ley³.

Así las cosas, los fondos provenientes de cooperación financiera, que se cataloguen como fondos públicos, se encuentran, por tal condición, sujetos a un marco de aprobaciones, controles, evaluación y rendición de cuentas que, en lo sustancial, no difiere del que cubre a los fondos públicos originados en otras fuentes de recursos. Adicionalmente, entre los entes y órganos que tienen una participación destacada en estos procesos, se encuentran: la Asamblea Legislativa, algunas dependencias del Ministerio de Hacienda, Tesorería Nacional, Autoridad Presupuestaria, MIDEPLAN, Banco Central de Costa Rica y la Contraloría General de la República.

Por su parte, las normas que cobijan la cooperación técnica internacional, como también se ha podido apreciar, asignan ciertos papeles a MIDEPLAN y al MRREE, durante las etapas previas a que se ejecute la cooperación técnica (que incluyen la formulación, negociación y aprobación), así como en su evaluación, actividades, todas ellas, que se rigen por las normas de planificación, eva-

3. Procede destacar que el artículo 6 de la Ley de Modernización del Sistema Financiero de la República, n. 7107 , exceptuó del alcance del artículo 9 de la Ley n. 5525 , al Banco Central de Costa Rica, a los bancos del Estado, al Banco Popular y de Desarrollo Comunal y al Banco Hipotecario de la Vivienda. 
luación y rendición de cuentas, aplicables a todo el aparato estatal.

d) El Consejo Técnico de la Cooperación Internacional

Parte de la institucionalidad responsable de diversas tareas en torno a la cooperación internacional en general incluye el Consejo Técnico de la Cooperación Internacional, creado mediante el Decreto Ejecutivo n. ${ }^{\circ}$ 35056-PLAN-RE, órgano de coordinación constituido recientemente y conformado por jerarcas de MIDEPLAN y MRREE, que tiene entre sus objetivos asegurar que la cooperación recibida u otorgada por el país, guarde coherencia con el PND y con su política exterior, así como, conformar los comités técnicos o grupos de trabajo que sean necesarios para las distintas modalidades de cooperación internacional que el país reciba u otorgue. El Consejo Técnico facilita la tramitación expedita de programas, proyectos y acciones de cooperación internacional no reembolsable; elabora un plan de trabajo al inicio de cada Administración y en forma anual, con base en el PND y la Agenda Sectorial de Cooperación Internacional; presenta informes conjuntos entre ambos Ministerios; y procura una evaluación constante de los programas, proyectos y acciones de cooperación, a partir de informes que MIDEPLAN elabora 4 .

MIDEPLAN no solo es la entidad pública que en la actualidad dispone del más amplio mandato en materia de cooperación internacional, sino que, adicionalmente, le ha sido asignada, dentro del Sistema Nacional de Planificación, la condición de órgano

4. Para una mayor profundización acerca del ámbito de competencias que regula la cooperación internacional canalizada hacia nuestro país, véanse: MIDEPLAN (2007a) y MIDEPLAN (2007b), este último referido al marco jurídico que cubre dicha actividad. rector encargado de la administración del denominado "Sistema Nacional de Inversión Pública (SNIP)", con el propósito de optimizar el uso de los recursos públicos destinados a proyectos de inversión, entre ellos, los financiados con recursos provenientes de la cooperación internacional. El SNIP comprende: "el conjunto de normas, principios, métodos, instrumentos y procedimientos que tienen por objetivo ordenar el proceso de la inversión en la Administración Pública Central y Descentralizada, para poder concretar los proyectos de inversión más rentables para el país, desde el punto de vista del desarrollo económico, social y ambiental" (artículo 2 del Decreto Ejecutivo n. 35056PLAN-RE). El SNIP está conformado por cinco componentes, a saber: a) Metodologías de Formulación y Evaluación de Proyectos de Inversión Pública; b) Normas Técnicas, Lineamientos y Procedimientos de Inversión Pública; c) Banco de Proyectos de Inversión Pública; d) Capacitación en Inversión Pública; e) Plan Nacional de Inversión Pública (artículo 3 de ese mismo Decreto Ejecutivo). A MIDEPLAN le compete establecer y poner en operación dicho sistema con la finalidad de organizar el proceso de inversión pública, así como poner en operación, en forma gradual, cada uno de sus componentes.

Al final del presente documento, se incluye una figura que muestra el sistema de administración para la cooperación internacional que opera en nuestro país, el cual incluye el conjunto de normas, actores y procesos que lo conforman, así como las interacciones de dicho sistema con un contexto de políticas públicas dentro del cual opera. 


\section{Reforma jurídica}

a) Fondos públicos frente a fondos privados: apuntes para su diferenciación

Es de suma importancia señalar que el concepto fondos públicos no está constreñido al dinero en efectivo, sino que, al tenor del artículo 9 de la Ley Orgánica de la Contraloría General, "Fondos públicos son los recursos, valores, bienes y derechos propiedad del Estado, de órganos, de empresas o de entes públicos". Se tiene, entonces, que en el marco de la cooperación financiera no reembolsable, los bienes entregados al Estado y a sus instituciones se constituyen también en fondos públicos (PGR, 2008a). Ello implica que se vean activadas, según sea el caso, las normas que informan la materia de administración de fondos en efectivo (v.gr. sobre crédito público, ejecución y control presupuestario y sistema de caja única) o bien, las normas referidas al trámite de donaciones de bienes, obras o servicios.

En cuanto a las normas referidas a la donación de bienes, los artículos 103 de la LAFRPP y 19 del Reglamento para el Registro y Control de Bienes de la Administración Central, Decreto Ejecutivo n. $30720-H$ de 26 de agosto de 2002, abarcan lo referido a la entrega, aceptación y registro de los bienes donados u obsequiados a favor del Estado. Asimismo, la Contabilidad Nacional emitió la Directriz n. ${ }^{\circ}$ CN 002-2006 del 23 de marzo de 2006, denominada "Directriz dirigida a todas las entidades del Estado que tienen a su cargo aquellos casos en los que se pueda generar un ingreso o gasto potencial", publicada en La Gaceta n. 133 del 11 de julio de 2006, cuando resulte aplicable.

A propósito de la donación de bienes, en fechas recientes la Contraloría General emitió dos informes que abordaron este tema. En el primero de ellos (CGR, 2008b) se indicó, entre otros aspectos, que la Contabilidad Nacional no ha realizado gestiones ni ha emitido instrucciones y procedimientos para que los bienes recibidos en donación por el Poder Ejecutivo, sean registrados en el denominado Sistema de Administración de Bienes (SIBINET); además, se determinaron casos de activos donados que no habían sido registrados en la Contabilidad Nacional. Se giraron instrucciones al Ministro de Hacienda, tendentes a ordenar la revisión y ajuste de procedimientos que conduzca al debido registro contable de los activos recibidos mediante donaciones. En el segundo informe (CGR, 2009), relacionado con la ejecución de los recursos suministrados por el BCIE al Ministerio de la Presidencia, se determinó que, en el caso de los bienes adquiridos con dichos recursos, ese Ministerio no había cumplido con la normativa relativa al registro y control de bienes, incluyendo lo referido al registro, en el citado Sistema, de los bienes recibidos.

Siguiendo a la Procuraduría General de la República (2008a), hay que señalar que:

Una donación puede tener como objeto un bien material, un servicio, un recurso financiero, sean valores, dinero en efectivo. Cuando la donación se otorga a un ente público, el bien donado tiene como destino el patrimonio del ente, un patrimonio público, y como tal puede ser considerado fondo público en los términos del artículo 9 de la Ley Orgánica de la Contraloría General de la República, antes transcrito. Lo donado, entonces, es parte de la Hacienda Pública a partir de la eficacia de la donación (p. 33).

Por eficacia de la donación nos referimos al momento en que el Estado costarricense adquiere la titularidad de lo donado, sea esto dinero en efectivo, bienes materiales o servicios. Para el caso de los fondos líquidos, la eficacia se materializa cuando los fondos son entregados al Estado; para el caso de los bienes, a partir del traslado de propiedad a favor de este último; para el caso de los servicios, en su prestación y cuando se reciben los productos que se derivan de ellos. Tal eficacia deviene en elemento medular que 
orienta la determinación de la naturaleza pública o privada de lo donado, sea esto dinero en efectivo, bienes materiales, servicios o valores, amén de que, en orden a los fondos de origen privado, ayuda a esclarecer cuándo opera su transformación en fondos públicos. A ese respecto hay que destacar, siguiendo a la Procuraduría General (2004), que en los casos de donación de fondos líquidos: ". . cabría considerar que a partir de que la donación se haga efectiva, se está en presencia de fondos públicos" (p. 10).

Los términos y condiciones para la administración de los recursos, que el cooperante y el receptor lleguen a acordar en cada cooperación particular, pueden tener una incidencia directa sobre su calificación como fondos públicos o privados. Esto ha hecho necesario que, en no pocos casos, se deba acudir a una valoración de orden casuístico para dilucidar la naturaleza de los fondos involucrados. En este sentido, la Contraloría General ha señalado que las potestades y atribuciones de percepción, administración, custodia, manejo, gasto e inversión de los fondos, que cobije a las partes que participan en cada cooperación, así como las potestades administrativas y financieras relativas al proceso presupuestario, la contratación administrativa, el control interno y externo y la responsabilidad de los funcionarios públicos, resultan características sustanciales para la definición y determinación de la naturaleza pública o privada de tales fondos (CGR, 2007).

No son extraños los casos en los que se manifiesta una voluntad expresa del donante o cooperante, de que los recursos aportados no sean ingresados a la corriente de los fondos públicos. Por otra parte, tampoco existe norma jurídica en nuestro ordenamiento que prohíba o limite en forma expresa y genérica, la posibilidad de que el Estado y sus instituciones reciban bienes y servicios resultantes de la utilización de fondos de cooperación administrados por el propio do- nante ${ }^{5}$ o por un tercero; ello, en tanto estemos ante el siguiente cuadro de situación:

- Que no exista una disposición expresa que lo prohíba o limite en algún caso en particular.

- Que la donación esté dirigida al cumplimiento de los fines públicos encomendados a la Administración.

- Que el destino de la donación se encuentre en relación con las funciones que corresponden al organismo público receptor; y

- Que la donación sea incondicionada, sea, que el donante no imponga condicionamientos en aspectos tales como la forma en que donatario debe cumplir las funciones que el ordenamiento le ha encomendado o bien, hacia qué debe dirigir los fondos recibidos (PGR, 2000).

Ahora bien, se tiene el caso de aquellas cooperaciones financieras no reembolsables en las que el donante o un tercero administra los fondos líquidos y con ellos adquiere o produce bienes que entrega al beneficiario público, sin que este haya disfrutado en ningún momento del poder de disposición sobre dichos fondos líquidos. En tal situación, durante ese período previo a que se produzca la eficacia de la donación, los fondos correspondientes se encontrarían revestidos

5. MIDEPLAN (2007 a) señala que la administración de los recursos externos por parte de los mismos donantes, es la modalidad más utilizada hasta el momento en Costa Rica. Tal es el caso de la Agencia de Cooperación Técnica Alemana (GTZ), los países nórdicos que aportan cooperación al país, como es el caso de Suecia, y el Fondo de Población de Naciones Unidas (UNFPA), entre otras. También se tiene la modalidad de recursos administrados por organismos internacionales (Programa de las Naciones Unidas para el Desarrollo -PNUD- y Banco Interamericano de Desarrollo -BID), cuya fuente corresponde a su vez a algún gobierno o bien, a otro organismo internacional, público o privado. 
de naturaleza privada. Señala la Procuraduría (2008a) que:

Cuando se donan bienes o servicios, como sucede en los convenios de cooperación mencionados anteriormente, los recursos que financian la contratación de lo donado no constituyen fondos públicos y, por ende no se sujetan al régimen jurídico costarricense. Estos recursos se regirán, entonces, por las normas que regulan al donante $y$, consecuentemente, será con base en esas normas que podrá establecerse la naturaleza de los fondos. Lo importante es que en esos supuestos el dinero con que se paga no es un fondo público costarricense $y$, por ende, no se rige por nuestra legislación. Por el contrario, cuando el bien o servicio se done a un ente público, a partir de la eficacia de la donación, este formará parte de la Hacienda Pública, sea porque pasa a ser un bien de patrimonio público, sea porque respecto de él podrán ejercerse las potestades propias de la Hacienda Pública según define el artículo 8 de la Ley Orgánica de la Contraloría General de la República. Consecuentemente, la eficacia de la donación permite a la Contraloría General ejercer sus potestades sobre el bien o servicio donado. Es el caso, por ejemplo, de la donación de un vehículo, de un estudio técnico o de un puente, cuyo carácter público deriva del traslado de propiedad a favor de un organismo público. Con lo anterior indicamos, además, que puede haber cooperación técnica no reembolsable y que esta puede consistir en asesorías, estudios de factibilidad de proyectos, entre otros aspectos. / En ese orden de ideas, cabe recordar que la donación de bienes y servicios contratados por el donador es una práctica habitual dentro de la cooperación internacional. . . No sería razonable que un Estado adujera que como donación únicamente puede recibir dinero en efectivo." (pp. 37-38).
Además ha indicado (2008a) que:

"...en la donación de bienes y servicios debe diferenciarse entre el régimen de los recursos con los cuales los servicios y bienes son adquiridos y el régimen del bien o servicio una vez donado...Como el Gobierno de la República no recibe recursos financieros, resulta improcedente la aplicación de las normas nacionales referidas a la presupuestación y gestión de esos recursos. Ergo, un control previo sobre la actividad de presupuestación y contratación" (pp. 47-48).

Tratándose de fondos de naturaleza privada, el ordenamiento jurídico se ha centrado en los deberes que le caben a la administración pública receptora de los fondos -entendidos éstos en su amplia acepción, que incluye el recibo de bienes y servicios-, en particular, los deberes en materia de compatibilidad de los planes institucionales y programas de inversión, con el PND (que abarca elementos de planificación, rendición de cuentas y evaluación), así como las autorizaciones y aprobaciones emitidas por MIDEPLAN que forman parte del trámite de obtención de recursos para el financiamiento de proyectos de cooperación internacional, deberes comprendidos en la Ley n. 5525 y en su Reglamento, así como en la Ley n. 8131 y en su Reglamento. Por regla general, la recepción de los fondos líquidos, su conservación, inversión y desembolso, así como la contratación de los bienes y servicios que son el objeto de la cooperación, en tales casos corren por cuenta del cooperante o de un tercero. Ello, sin perjuicio de los deberes y facultades que las partes -cooperante y receptor- hayan acordado que este último ejerza, los cuales quedan plasmados en el instrumento convencional o contractual que hayan suscrito para reglar el manejo de la cooperación (v.gr. carta de entendimiento, convenio de cooperación, contrato de 
fideicomiso ${ }^{6}$, etc.), cuyos alcances podrán variar en cada caso particular. De igual forma, las potestades que el artículo 8 de la Ley Orgánica de la Contraloría General de la República, le otorga al órgano contralor en relación con el proceso presupuestario, la contratación administrativa, el control interno y externo, se encuentran delimitadas por el marco de deberes, atribuciones y facultades de las entidades públicas a las que se destinan los bienes y servicios provenientes de fondos de naturaleza privada, en especial lo que al respecto hayan acordado las partes (cooperante y beneficiario) en los instrumentos convencionales o contractuales correspondientes.

Para el caso de los bienes y servicios provenientes de donantes externos, las Normas de control interno para el Sector Público vigentes, promulgadas por la Contraloría General, establecen el deber de los jerarcas y titulares subordinados, por establecer, mantener, perfeccionar y evaluar las actividades de control necesarias en relación con dichos bienes y servicios, sean estos obtenidos bajo la modalidad de donación, cooperación técnica o cooperación financieras no reembolsable; que se ejerzan los controles de legalidad, contables, financieros y de eficiencia que determina el bloque de legalidad; asimismo, que tales bienes y servicios cumplan con la condición de satisfacer fines públicos y estén conformes con los principios de transparencia, rendición de cuentas, utilidad, razonabilidad y buena gestión administrativa (norma 4.5.5 del Manual).

b) Consideraciones sobre los proyectos de reforma a las atribuciones de la Contraloría General para la fiscalización de recursos de cooperación internacional

6. Los patrimonios fideicometidos que se constituyen con fondos privados provenientes de cooperación internacional, no han de confundirse con diversos fideicomisos que, si bien pueden enmarcarse dentro de la filosofía de la cooperación internacional, se constituyeron o ratificaron mediante sanción legislativa y, por ende, se encuentran revestidos de carácter público.
A la Contraloría General y a la Auditoría Interna, como componentes del Sistema de Control y Fiscalización Superior de la Hacienda Pública, les cabe la facultad de examinar las actuaciones de los entes y órganos públicos involucrados en la cooperación (entidad receptora, MIDEPLAN u otros), en aquellos ámbitos regidos por las normas contenidas en el ordenamiento jurídico costarricense o integradas a éste, así como en relación con el ejercicio de aquellos deberes y facultades que los instrumentos convencionales o contractuales en donde se plasmó la cooperación, hayan depositado en las administraciones públicas.

En años recientes ingresaron a la corriente legislativa, dos proyectos de Ley que han propuesto modificaciones a los artículos 8 y 9 de la Ley Orgánica de la Contraloría General, tramitados en su oportunidad bajo los expedientes n. 15516 "Ley de Pacto Fiscal y Reforma Fiscal Estructural" y n. ${ }^{\circ} 16505$ "Ley que modifica los artículos 8 y 9 de la Ley n. ${ }^{\circ} 7428$, Ley Orgánica de la Contraloría General de la República."

Si bien ambas iniciativas resultan loables en términos del fortalecimiento del control y la fiscalización de tales recursos, es menester aclarar que las reformas propuestas no logran modificar de forma sustancial el ámbito de atribuciones y competencias conferidas en la actualidad a la Contraloría General; tampoco alcanzan a revestir de una naturaleza pública forzosa, a todos aquellos fondos que, por voluntad expresa de las entidades donantes o cooperantes, se resuelva que no sean ingresados a la corriente de los fondos públicos -no estando esas entidades, por ende, obligadas a introducirlos a dicha corriente-, ni nuestro ordenamiento jurídico cuenta con normas que prohíban o limiten en forma expresa y genérica, la posibilidad de que el Estado y sus instituciones reciban bienes y servicios resultantes de la utilización de fondos de cooperación administrados por el propio donante o por un tercero, según ya se había señalado con anterioridad. 
Con respecto al expediente n.' 15516, la reforma propuesta adiciona un párrafo tercero al artículo 8, que establece que "Se entenderá como parte de ese patrimonio [público] los activos que se adquieran con fondos de donaciones y así deberán ser registrados para todos los efectos". La reforma propuesta al artículo 8 en el expediente

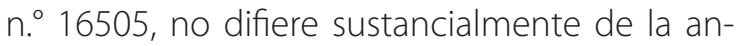
terior, pues señala expresamente que el patrimonio público se compone, entre otros, por: "Ios activos adquiridos mediante donaciones $u$ aportes de organismos internacionales". De igual manera, la reforma que se introduciría al artículo 9 en el expediente n. 15516 establece que:

Los fondos públicos son los recursos, valores, bienes y derechos propiedad del Estado, de órganos, de empresas, o de entes públicos; $y$ todos aquellos aportes, donaciones o empréstitos de gobiernos extranjeros, entidades financieras multilaterales, o de instituciones privadas internacionales o nacionales, destinados al cumplimiento, en instancia paralela, de competencias estatales.

Similarmente, la reforma propuesta a dicho artículo en el expediente n. ${ }^{\circ}$ 16505, adiciona en forma expresa la mención de que los fondos aportados al Estado mediante donaciones, empréstitos de gobiernos extranjeros, entidades financieras multilaterales, o de instituciones privadas internacionales o nacionales, constituyen parte del universo de fondos públicos.

El propósito que han perseguido las propuestas de enmienda normativa no sería satisfecho con los ajustes que le serían eventualmente introducidos a la Ley Orgánica de la Contraloría General. De hecho, el obstáculo de tal pretensión radica en que el bloque de legalidad, así como la jurisprudencia emanada de él, han delimitado una frontera en lo que se refiere a la naturaleza de los fondos de cooperación, según se ha venido reseñando a lo largo de esta exposición. Así las cosas, este ámbito acotado de control y fiscalización para el caso de los fondos privados, si bien a juicio de algunos operadores jurídicos puede resultar insuficiente, responde al marco trazado por el ordenamiento vigente, con la particularidad, para el caso de los cooperantes que sean a su vez entes de derecho público internacional, de encontrarse resguardados por un cuerpo particular de reglas constitucionales que les cubren?.

c) El papel preponderante de MIDEPLAN en la actividad de cooperación internacional, frente al eventual rediseño del marco normativo e institucional que rige la actividad

La prensa informó acerca del interés que mantenía la administración Arias Sánchez (período 20062010) por constituir una agencia de cooperación internacional, lo que implica la elaboración de un proyecto de ley de creación de dicha agencia, actividad que corre a cargo de MIDEPLAN. Según se ha indicado, la agencia centralizaría toda la información referente a la cooperación internacional gestionada por el Estado, buscaría ayuda extranjera por medio de personal que sería destacado en las sedes diplomáticas de aquellos países que proveen la mayor parte de los recursos de cooperación financiera y técnica, ejecutaría proyectos concretos de cooperación y atendería las necesidades de cooperación técnica formuladas ante nuestro país.

Ahora bien, como se ha venido reseñando, a MlDEPLAN le ha sido depositado un mandato muy amplio en materia de cooperación internacional, el cual abarca, entre otros: formulación, negociación,

$7 \quad$ A efectos de ahondar en lo tocante al ordenamiento constitucional y legal, que cobija a los convenios marco de cooperación cubiertos por el artículo 7 de la Constitución Política, véase PGR, 2003b. Por su parte, respecto de los límites bajo los cuales se enmarcan las relaciones de cooperación internacional que se establezcan entre el Estado costarricense y las entidades cooperantes que revisten la condición de personas de Derecho Internacional Público cobijadas por los artículos 7 y 121 de nuestra Carta Fundamental, véanse PGR, 2008a y PGR, 2008 b. 
coordinación, aprobación y evaluación de programas de asistencia técnica; emisión de autorizaciones de previo a que los entes y órganos del Gobierno Central y del sector descentralizado inicien los trámites para obtener cooperación internacional; evaluación de la congruencia, con respecto al PND, de los programas de cooperación, en especial los destinados a la realización de inversiones públicas; emisión de autorizaciones de previo a que se inicien las gestiones para obtener créditos externos; aprobación de los proyectos de inversión de los organismos públicos, cuando estos últimos incluyan total o parcialmente financiamiento externo o requieren aval del Estado para su financiación; así como, algunas competencias y funciones relacionadas con la asignación, ejecución y evaluación de fondos o proyectos especiales de preinversión o financiamiento para el desarrollo, así como de proyectos de Inversión Pública.

Hay que destacar que una parte sustancial de los recursos de cooperación internacional se destinan a erogaciones ejecutadas bajo la forma de proyectos y programas. En meses recientes ingresó a la corriente legislativa, bajo el expediente . $^{\circ}$ 17117, el proyecto de Ley de Creación del Sistema Nacional de Evaluación Permanente de las políticas públicas y la calidad de los servicios (Evapol), el cual se encontraría adscrito a MIDEPLAN y tendría por finalidad:

...promover y realizar permanentemente la evaluación de las políticas y los programas públicos, para garantizar el uso racional de los recursos públicos y el impulso a la gestión de la calidad de los servicios. Evapol tendrá entre sus objetivos fomentar la evaluación, mediante la capacitación sistemática, el soporte técnico, la creación de estándares y la vinculación con redes afines de otros países; asimismo, la difusión de los resultados de las evaluaciones que se apliquen $y$, en general, la promoción de la cultura de evaluación en todo el Sector Público.
El proyecto reformaría el artículo 9 de la Ley de Planificación Nacional, n. ${ }^{\circ}$ 5525, al elevar a rango legal el deber de MIDEPLAN de elaborar, cada cuatrienio, el denominado Plan Nacional de Inversión Pública, compuesto por proyectos seleccionados siguiendo las prioridades del Plan Nacional de Desarrollo y jerarquizados mediante la aplicación de métodos de evaluación social de proyectos. Además, la reforma al citado artículo hace explícito el deber que le cabe a MIDEPLAN de evaluar el desempeño de los proyectos de inversión pública, tanto en la etapa de implementación como en la de operación, así como la obligación de publicar los resultados correspondientes. Además, en lo que nos interesa, sea, los recursos provenientes de la cooperación internacional, el artículo 2 del proyecto señala, entre otros aspectos, que "...la evaluación será extensiva a las agencias y los proyectos privados independientes de la Administración Pública, cuando reciban fondos públicos."

Adicionalmente, dentro de la estructura organizativa de MIDEPLAN se encuentra la Dirección Ejecutora de Proyectos (DEP), que por imperativo legal administra los fondos de cooperación internacional del Programa PL-480, así como otras fuentes de recursos internacionales; al respecto, mediante la Ley n. 7307 se ratificó el "Convenio entre la Commodity Credit Corporation, una Agencia de los Estados Unidos de América y el Gobierno de Costa Rica, para la venta de productos agrícolas". De conformidad con el inciso C.2 del Anexo n. ${ }^{\circ} 1$ al referido Convenio:

Costa Rica conviene en mantener adscrita a MIDEPLAN una Dirección Ejecutora de Proyectos (DEP) responsable ante el Ministro, para que lleve a cabo, entre otras cosas, las funciones descritas en los párrafos C.1 y C.2 del presente Anexo No 1. La DEP también será responsable de planear, promover, administrar, controlar, contabilizar e informar sobre el uso de moneda local que se genere 
bajo el Convenio de Venta. Además deberá identificar y determinar prioridades, apoyar la formulación de programas y proyectos de desarrollo, canalizarlos ante las instancias correspondientes y apoyar las gestiones de financiamiento y asistencia técnica, de acuerdo con las estrategias y prioridades que determine el Plan Nacional de Desarrollo.

El inciso C.3.a) de dicho Anexo establece además lo siguiente:

La DEP se financiará en primer término con recursos originados en el Convenio de Venta, para lo cual se faculta a MIDEPLAN para que administre y deposite dichos recursos en la cuenta especial abierta para tales propósitos en un banco estatal del Sistema Bancario Nacional. Al mismo tiempo, la DEP podrá administrar recursos provenientes de préstamos, donaciones, otras fuentes de financiamiento, así como otras actividades que están a cargo de MIDEPLAN, los cuales se depositarán en cuentas específicas para cada fuente.

Además, esa Dirección también ejecuta proyectos, actividad que, como ya se indicó, se pretende que sea llevada a cabo también por la agencia de cooperación internacional que estaría siendo conformada.

Según se ha podido observar, tanto la legislación vigente como las propuestas de enmienda normativa, depositan en MIDEPLAN, en su calidad de órgano rector del sistema de planificación nacional, el abanico más amplio de atribuciones y competencias, en materia de cooperación internacional, así como en lo relativo a otros procesos y actividades que resultan medulares para la efectividad y transparencia de dicha cooperación, a saber: el vínculo de los planes, programas y proyectos institucionales con el Plan Nacional de Desarrollo, el seguimiento y la evaluación ex ante y ex post de los programas y proyectos de inversión y de desa- rrollo, el endeudamiento público, la rendición de cuentas y algunas actividades de control.

MIDEPLAN Ilevó a cabo, en el año 2007, una diagnosis del sistema de cooperación internacional que opera en Costa Rica, fruto de la cual se emitió el documento titulado Diagnóstico de la Cooperación Internacional en Costa Rica 20002005 (MIDEPLAN, 2007a). Entre los resultados y conclusiones más relevantes del estudio, no se incluye la constitución de una nueva dependencia que asuma tareas que el ordenamiento ha depositado primordialmente en MIDEPLAN y en menor grado en el MRREE. De hecho, las deficiencias señaladas en dicho diagnóstico en relación con la falta de claridad en las acciones de coordinación y en la delimitación de las funciones que cubren a MIDEPLAN y al MRREE, la carencia de información centralizada y sistematizada sobre la cooperación internacional, y la ausencia de estandarización de los procesos de cooperación, han venido siendo solventadas recientemente, mediante ajustes que no han requerido de normas de rango legal, tal es el caso del Decreto Ejecutivo n. ${ }^{\circ}$ 35056-PLAN-RE del 12 de noviembre de 2008, que reglamentó el artículo 11 de la Ley de Planificación Nacional, y la Directriz Presidencial n. ${ }^{\circ} 030-P L A N$ del 10 de setiembre de 2008, referida a la remisión, a MIDEPLAN, de parte de todos los órganos e instituciones de la Administración Central, de información actualizada sobre acciones de cooperación no reembolsable. Mediante esta Directriz Presidencial, se le ordenó a todos los órganos e instituciones de la Administración Central, que remitieran al MIDEPLAN la información disponible sobre acciones y medidas de cooperación internacional y nacional no reembolsables vigentes, con la finalidad, según se indica, de “. . mantener información precisa y puntual sobre la cooperación, que facilite los procesos de transparencia en las actuaciones del Estado y una adecuada rendición de cuentas de la gestión pública" (artículo $1^{\circ}$ ). Por su parte, el artículo $2^{\circ}$ estableció que: 
La información requerida deberá ser enviada en formato digital y contendrá como mínimo lo siguiente: a) nombre de la actividad; b) entidad ejecutora o responsable; c) fuente de financiamiento; d) objetivos de la contratación; e) tipo de contratación; f) copia de los términos de referencia; g) nombre de las personas físicas o jurídicas contratadas; h) monto de la contratación; i) período de vigencia de la contratación.

En el artículo $4^{\circ}$ se estableció que “El Área de Cooperación Internacional de MIDEPLAN realizará las gestiones necesarias para mantener la información actualizada y disponible para consulta de la ciudadanía.."

\section{Rendición de cuentas y transparencia en la gestión de la cooperación internacional compuesta por fondos de naturaleza privada}

Ya se ha indicado que a los recursos de cooperación internacional calificados como fondos públicos, los cubre un marco de aprobaciones, controles, evaluación y rendición de cuentas que, en lo medular, no difiere del que cubre a los fondos públicos originados en otras fuentes de recursos. Adicionalmente, se ha señalado que la segunda Administración Arias Sánchez (20062010) se dio a la tarea de constituir una agencia de cooperación internacional, lo que implica la elaboración de un proyecto de ley de creación de dicha dependencia.

Dados los aspectos antes indicados, interesa poner el acento, en estas últimas líneas, en la gestión de cooperación internacional con recursos calificados como de naturaleza privada. Ello bajo el argumento, ya expuesto, de que en tratándose de recursos de cooperación internacional, el bloque de legalidad, la jurisprudencia y la doctrina, han establecido un cuerpo de premisas y condiciones que hacen distinción respecto de cuándo estamos frente a fondos públicos y en qué situación frente a fondos privados $y$, en consecuencia, crea diferencias con respecto al conjunto de normas de gestión, control, rendición de cuentas y fiscalización que les resultan aplicables a cada una de estas dos categorías de fondos; normas que ya han sido mencionadas con anterioridad.

Los estudios de fiscalización que la Contraloría General ha realizado sobre la ejecución de programas y proyectos de cooperación internacional, cuyos fondos han sido calificados como de naturaleza privada, han evidenciado ciertos aspectos de la gestión que presentan deficiencias importantes. En estrecha síntesis, entre esos aspectos deficientes se encuentran: carencia de elementos básicos de planificación, tales como: indicadores, metas y actividades; ausencia o falta de claridad de criterios para la priorización y asignación del gasto; deficiencias en los procesos de contratación de bienes y servicios; expedientes de los contratos incompletos; manejo de recursos al margen de las prácticas propias de la administración de proyectos; carencia de estructura organizativa para el control y seguimiento; falta de delegación formal de las responsabilidades, débil papel ejercido por el administrador de los fondos privados, sea éste el propio organismo cooperante o una entidad comisionada para tal propósito; control y seguimiento débiles o insuficientes de parte del ente u órgano público beneficiario; falta de claridad acerca de los productos brindados por los consultores; ausencia de rendición de cuentas y de evaluaciones de impacto en relación con los programas y proyectos financiados con la cooperación; ausencia de documentación formal de los procesos; así como, información escasa, dispersa, inexacta o incompleta (CGR, 2005 y CGR, 2008a).

Como bien indicó la Contraloría General (2008a), estas deficiencias en la gestión de los recursos de cooperación financiera no reembolsable, han conducido, respecto de las responsabilidades que le caben a la entidad pública beneficiaria de la cooperación, a que: 
...el accionar...en torno a las consultorías no se ajustara a los principios fundamentales establecidos en el ordenamiento jurídico, orientados a la transparencia, rendición de cuentas y evaluación de resultados, que deben ser de observación obligatoria por parte de los funcionarios públicos, de forma tal que los actos y decisiones que adopten en el ejercicio de sus cargos sean debidamente motivados y puedan ser evaluados (p. 26).

Se señaló también (2008a) que las entidades públicas ejecutoras o beneficiarias de cooperación financiera no reembolsable deben brindar: “...las condiciones suficientes para garantizar el debido cumplimiento del ordenamiento correspondiente" (p. 34).

En otras palabras, en cuanto a los fondos de cooperación internacional que revisten carácter privado, en el meollo de las deficiencias de gestión identificadas por el órgano contralor, se encuentra la concepción reinante entre los administradores de la res pública, de que el incremento en el nivel de efectividad en la gestión de estos fondos, pasa necesariamente por una extrema simplificación de las estructuras funcionales, procesos y procedimientos que deben regir el manejo de los recursos y, en algunos casos, por la desatención de normas del ordenamiento jurídico, condiciones que han sido justamente las que han provocado el debilitamiento de los sistemas de control interno, de evaluación y de rendición de cuentas, así como, eventualmente, infracciones al ordenamiento vigente; de ahí que la evidencia sugiere que en la explicación de dichas deficiencias de gestión, el factor humano ha venido teniendo un mayor peso que las posibles falencias en el diseño normativo. A modo de ejemplo, la investigación por parte del órgano contralor, de los casos relacionados con los aportes internacionales destinados al Ministerio de la Presidencia y al MlVAH, condujeron al envío de tres documentos al Ministerio Público sobre la gestión de los recursos destinados al MIVAH, asimismo, se llevó a cabo la remisión interna, a la División de Asesoría y Gestión Jurídica de la Contraloría General, de una Relación de Hechos, con la finalidad de que esa División valorara la apertura de los procedimientos administrativos pertinentes, por la ausencia de un adecuado sistema de control interno que debió prevalecer en el Ministerio de la Presidencia al momento de la selección y recomendación de consultores ante el BCIE.

A ese respecto, si bien no se objeta, per se, que se diseñen y pongan en ejecución diversas formas de administración de los recursos, es claro que a lo largo de los últimos años, buena parte del control político y ciudadano en relación con este tema, se ha orientado a demandar un mínimo de controles exigibles para estos recursos. Ahora bien, el marco normativo vigente, así como la jurisprudencia que de él se deriva, hacen clara distinción entre el ámbito de controles que cubre a los fondos, según sean catalogados como públicos o como privados, de forma que, para este segundo caso, la posibilidad de que los instrumentos convencionales o contractuales que suscriben las partes, incorporen elementos a nuestro juicio sustanciales -como lo sería el sometimiento a los principios que informan la contratación administrativa y a un cuerpo básico de normas de control interno, rendición de cuentas y transparencia- está quedando en buena parte librado al acuerdo entre partes (cooperante y administración pública receptora).

No hay que ignorar que la tonalidad de los controles puede llegar a ser propuesta directamente por el organismo cooperante, según sus propias reglas en materia de administración de fondos y contratación de bienes y servicios. No obstante, también existen casos en los que cabe la posibilidad de que el organismo de cooperación se allane a algún tipo de mecanismo de gestión de los recursos que sea propuesto por el ente u órgano público receptor, o bien, que tal mecanismo sea diseñado y pactado motu proprio entre las par- 
tes (cooperante y receptor), obligación a la cual, a nuestro juicio, el Estado se encuentra llamado a explorar y promover, mediante canales oficiales, en las etapas de solicitud de fondos y de diseño del mecanismo de administración de los recursos. Por ejemplo, las prácticas de contratación administrativa de bienes y servicios seguidas por los administradores de estos fondos, al no encontrarse cubiertas por las normas -ni aún por los principios- que informan la contratación administrativa pública, han conducido a una discrecionalidad muy elevada -que se reputa incluso excesiva- con lo cual, los fondos en no pocos casos han sido manejados de forma poco rigurosa.

El argumento que algunos jerarcas públicos han esgrimido en su oportunidad, en orden a que lo que se persigue es justamente el manejo de fondos prescindiendo de la aplicación de los principios de la contratación administrativa pública, a nuestro criterio debe ser necesariamente confrontado con el evidente interés público y las amplias demandas ciudadanas, de dotar a las contrataciones de un grado de rigor que propicie, no solo la eficiencia del proceso contractual, sino también, la libre participación y la transparencia del procedimiento. Procede destacar que entre los resultados a los que arribó la Contraloría General de la República en sus informes de fiscalización relativos a los fondos de cooperación de naturaleza privada, administrados por FUCE y por el BCIE (CGR, 2005 y CGR, 2008a), se destacaron las debilidades presentes en los procesos y procedimientos de contratación de bienes y servicios.

\section{CONCLUSIONES Y DISCUSIÓN}

A lo largo de esta investigación, se ha podido acreditar que los recursos de cooperación internacional calificados como fondos públicos, se encuentran sujetos a un ámbito de aprobaciones, controles, evaluación y rendición de cuentas que, en lo medular, no difiere del que cubre a los fondos públicos originados en otras fuentes de recursos. Por su parte, siempre en relación con la naturaleza de los fondos aplicados en las actividades de cooperación internacional, procede concluir que el bloque de legalidad, la jurisprudencia y la doctrina, han establecido un cuerpo de premisas y condiciones que hacen distinción respecto de cuándo estamos frente a fondos públicos y en qué situación frente a fondos privados y, en consecuencia, crea diferencias con respecto al conjunto de normas de gestión, control, rendición de cuentas y fiscalización que les resultan aplicables a cada una de estas dos categorías de fondos, según se ha mencionado en el presente documento.

La evidencia empírica recabada no aportó elementos de apoyo a la posición de quienes defienden que la introducción de reformas en el marco normativo que rige la cooperación internacional en Costa Rica, pueda resultar un medio efectivo para modificar ciertas prácticas calificadas como deficientes o irregulares, que se han venido presentando en el curso de los últimos años, en la gestión de algunas cooperaciones internacionales; más bien, la evidencia sugiere que en la explicación de dichas deficiencias de gestión, el factor humano ha venido teniendo un mayor peso que las posibles falencias en el diseño normativo. De toda suerte, según se ha indicado en esta investigación, cuando nos encontramos de frente a fondos de cooperación calificados como privados, el bloque de legalidad vigente, así como, la jurisprudencia emanada de él, han delimitado una frontera en lo que se refiere a la naturaleza de los fondos de cooperación, que da como resultado un ámbito acotado de control y fiscalización para el caso de dichos fondos privados, con la particularidad, para los cooperantes que sean a su vez entes de derecho público internacional, de encontrarse resguardados por un cuerpo particular de reglas constitucionales que les cubren, lo que obliga, como condición sine qua non, a que el diseño y puesta en rigor de cualesquiera nuevas normas de rango legal y reglamentario, eviten entrar en oposición a tales normas y principios de rango constitucional. 
A partir de la relación de deberes, atribuciones y competencias de MIDEPLAN, que se han descrito a lo largo del presente documento, resulta fundamental que las autoridades de la Administración Chinchilla Miranda, en el marco de sus reflexiones sobre la eventual constitución de la Agencia de Cooperación Internacional, ponderen cuidadosa y detalladamente, el papel que hasta la fecha se le ha asignado a MIDEPLAN y a sus dependencias, en el tema de la cooperación internacional. Esto, con el propósito de no desdibujarlo ni vaciarlo de contenido, pues existe el riesgo de que un eventual rediseño institucional produzca duplicidades que, lejos de volver más eficiente y efectivo el funcionamiento del aparato estatal, acaben tornándolo más ineficiente; adicionalmente, es menester que en la búsqueda de un modelo más ágil para la gestión de la cooperación, se conserve el fiel de la balanza, mediante el fortalecimiento y la preservación, dentro de esta actividad, de un conjunto de principios fundamentales para la democracia costarricense, como son: el diseño riguroso de los proyectos y programas a los que se destinen los fondos de cooperación, la rendición de cuentas por los resultados obtenidos, la transparencia en la gestión y el acceso sin cortapisas a aquella información que resulte del interés de los responsables del control político y ciudadano.

La coyuntura es propicia para que las autoridades de la actual Administración 2010-2014 efectúen un examen detallado de las atribuciones y competencias que llevan a cabo, tanto el Área de Cooperación Internacional de MIDEPLAN como la Dirección de Cooperación Internacional (DCI) de MRREE ${ }^{8}$, con miras a identificar eventuales duplicidades, actividades no atendidas, debilidades de coordinación y, en general, propiciar todos aquellos ajustes que resulten necesarios en las estructuras, procesos y actividades de MIDEPLAN y del

8. A efectos de ahondar en algunos aspectos asociados con la constitución de la DCl, vista desde la óptica del Ministerio de Planificación, consúltese MIDEPLAN (2007a).
Ministerio de Relaciones Exteriores, siendo que éstos son los principales actores institucionales que intervienen en la actividad de cooperación internacional. A modo de referencia, a inicios de la segunda Administración Arias Sánchez (20062010), MIDEPLAN formuló el proyecto denominado "Fortalecimiento de las Capacidades Institucionales para la Gestión de la Cooperación Internacional en Costa Rica 2007-2010", que tiene por objetivo fortalecer la capacidad institucional de gestión y organización de la cooperación internacional en Costa Rica, para así tener acceso y disponer de recursos externos que apoyen el desarrollo nacional de una forma ordenada, integrada y coherente, en consonancia con las prioridades establecidas en el Plan Nacional de Desarrollo 2006-2010; este proyecto se encuentra articulado en siete componentes, que abarcan reforma normativa, diseño de mecanismos novedosos de administración de recursos no reembolsables, diseño e implementación de sistemas de información y fortalecimiento del papel de MIDEPLAN en la negociación de los recursos de cooperación, entre otros aspectos (MIDEPLAN, 2007c).

Buena parte del éxito que pueda tener a futuro la gestión de cooperación internacional por parte de nuestro país, está asociado con un grado elevado de eficiencia en todas las etapas que constituyen la actividad de cooperación: identificación y evaluación ex ante de los proyectos y programas prioritarios para ser financiados por los recursos de cooperación; solicitud de recursos a los países y a los organismos de cooperación; diseño y negociación de los mecanismos de administración; definición y delimitación del marco de responsabilidades públicas por cada una de las actividades; instauración de sistemas de gestión de recursos financieros y de monitoreo y control del cumplimiento de los objetivos y metas trazados para el proyecto o programa; diseño y puesta en práctica de procedimientos de contratación de bienes y servicios; establecimiento de un sistema para la rendición de cuentas a los cooperantes, entes, órganos públicos y a la ciudadanía en general; así como evaluación ex post de resultados; entre otros elementos a considerar. 
Partiendo, como tesis de principio, de que cuando se trata de recursos de cooperación de naturaleza privada, el espacio que actualmente concede el ordenamiento jurídico vigente no permite un despliegue en toda su extensión de las competencias de fiscalización de la Contraloría General de la República y de las Auditorías Internas, este espacio requiere ser llenado, necesariamente, por decisiones políticas superiores apoyadas en un claro sustrato de ética pública, no planteada en abstracto, sino a partir de decisiones puntuales y concretas que busquen dar respuesta a interrogantes como las siguientes: ¿se encuentran las administraciones públicas dispuestas, sin excepción, a aceptar la cooperación internacional, bajo las reglas establecidas por el cooperante o donante? ¿el marco de políticas para la solicitud y concertación de recursos de cooperación debería incluir forzosamente la práctica de discutir con -y proponer a- los organismos cooperantes, la aplicación de un marco mínimo de principios de gestión, control, fiscalización, evaluación y rendición de cuentas, debidamente integrados al mecanismo de administración de los fondos, de forma que el cooperante se allane -bona fide- a ellos, o al menos, que quede clara y transparentemente documentada la posición oficial en contrario de parte del organismo donante, durante la etapa de negociación de la cooperación? ¿estarían dispuestas las administraciones públicas a renunciar a la obtención de recursos de cooperación internacional, en caso de que los organismos cooperantes se opusieran a adoptar ese marco mínimo de principios? ¿qué instrumentos normativos y de política pondrían en aplicación las administraciones públicas, para conciliar la aparente paradoja entre el resguardo de los principios de rendición de cuentas y de legalidad (artículos 11 de la Constitución Política y 11 de la Ley General de la Administración Pública) y el discurso de que es imprescindible manejar los fondos de cooperación internacional bajo modelos de administración notoriamente flexibles y con un grado elevado de discrecionalidad al momento de decidir la utilización de los recursos?
A modo de consideración final, interesa enfatizar en la importancia de seguir contando con flujos de recursos provenientes de la cooperación internacional, como medio para impulsar la ejecución de programas y proyectos que sean catalogados como prioritarios para nuestro país, con la mayor optimización posible de la relación beneficio-costo social. En ello, se ve una interesante ventana de oportunidad en las propuestas de reforma normativa tendentes a fortalecer la fase de evaluación exante de los programas y proyectos públicos -incluyendo, entre ellos, aquellos financiados con recursos de cooperación- de manera que las propuestas de los administradores públicos sean objeto de validación y queden revestidas de rigor técnico; de igual manera, las iniciativas para impulsar la evaluación ex post externa, indudablemente coadyuvarían a fortalecer la rendición de cuentas y la transparencia. Las debilidades que la Contraloría General ha podido acreditar con sus acciones de fiscalización posterior -como es el caso de los estudios realizados sobre la gestión de los fondos administrados por FUCE y por el BCIE- denotan que la fase de diseño de los proyectos y programas financiados por la cooperación internacional, es endeble, condición que podría verse atenuada con la participación de órganos técnicos de la administración pública, especializados en las diferentes ramas de la evaluación. Tampoco debe dejarse de lado que, ahí donde la normativa vigente no esté cubriendo algunos componentes de la actividad de cooperación internacional tal es el caso de la gestión de fondos calificados como privados- los administradores públicos se encuentran llamados a promover que el diseño y concertación de los instrumentos convencionales o contractuales para reglar el manejo de la cooperación (v.gr. carta de entendimiento, convenio de cooperación, contrato de fideicomiso, entre otros) comprendan un conjunto básico de principios de gestión, control, fiscalización, evaluación y rendición de cuentas, que vengan a armonizar con el mecanismo acordado para la administración de los fondos. 


\section{CONTEXTO}

Instancias a nivel macro:

- Consejo Técnico de la Cooperación Internacional

- Sistema Nacional de Inversión Pública

Modalidades de cooperación internacional

- Cooperación técnica

- Cooperación financiera reembolsable

- Cooperación financiera no reembolsable
Naturaleza de los recursos

- Fondos públicos

- Fondos de naturaleza privada
Proyectos de relevancia política para los gobiernos de turno

Cantidades elevadas de fondos

\section{COOPERACIÓN TÉCNICA}

Normas:

Ley de Planificación, Ley de Administración Financiera y Presupuestos Públicos (LAFRPP), Ley Orgánica de la Contraloría General (CGR)

\section{Actores:}

Ministerio de Planificación Nacional (MIDEPLAN), Ministerio de Relaciones Exteriores (MRREE), Contraloría General

Procesos:

- Aprobación y evaluación

- Estrategias de política exterior

- Planes de corto, mediano y largo plazo y su vínculo con PND

- Fiscalización externa posterior

\section{COOPERACIÓN FINANCIERA COMPUESTA POR FONDOS PÚBLICOS}

\section{Normas:}

Constitución Política, Ley de Planificación, LAFRPP, Ley CGR, Ley 7010, Ley 7558

\section{Actores:}

Asamblea Legislativa, dependencias del Ministerio de Hacienda, Tesorería Nacional, Autoridad Presupuestaria, MIDEPLAN, Banco Central (BCCR),

Contraloría General

\section{Procesos:}

- Presupuesto de la República

- Sistema de Caja Única

- Subsistema de Crédito Público

- Informes de resultados, evaluación y rendición de cuentas

- Controles y fiscalización externos previos y posteriores

\section{COOPERACIÓN FINANCIERA COMPUESTA POR FONDOS PRIVADOS}

\section{Normas:}

Ley de Planificación, Reglamento General de MIDEPLAN, LAFRPP, Ley CGR

\section{Actores:}

MIDEPLAN, Contraloría General

Procesos:

- Vínculo de programas de inversión pública con PND

- Autorizaciones y aprobaciones para obtener cooperación internacional

- Planes de corto, mediano y largo plazo y su vínculo con PND

- Fiscalización externa posterior, sobre competencias asignadas al ente u órgano público
Control político
Posicionamiento mediático

Ámbito prospectivo:

- Diagnósticos y propuestas de ordenamiento y eficiencia de la cooperación

- Enmiendas al marco normativo que rige la cooperación internacional

- Proyecto creación de Sistema Nacional de Evaluación Permanente de las políticas públicas y la calidad de los servicios

- Proyectos de reforma a las atribuciones de la Contraloría General para la fiscalización de los recursos de cooperación internacional 


\section{REFERENCIAS}

Contraloría General de la República - CGR (2005). Informe sobre el estudio relativo a la aplicación de los recursos donados al Gobierno de Costa Rica y recibidos por la Fundación de Cooperación Estatal (FUCE), para destinarlos al Programa de Reestructuración del Sector Público y de otros recursos que también administró FUCE. Informe n. DFOE-FEC-1-2005 del 4 de julio de 2005.

Contraloría General de la República - CGR (2007). Oficio n. 5018 (FOE-SOC-0387) del 16 de mayo de 2007.

Contraloría General de la República - CGR (2008a). Estudio especial sobre dos cooperaciones financieras no reembolsables aportadas por el BCIE en beneficio del Gobierno de la República de Costa Rica. Informe n. DFOE-SOC43-2008 del 22 de octubre de 2008.

Contraloría General de la República - CGR (2008b). Informe sobre el resultado del estudio realizado en la Contabilidad Nacional sobre el registro contable de Propiedad, Planta y Equipo y cuentas de orden. Informe n. DFOESAF-15-2008 del 18 de diciembre de 2008.

Contraloría General de la República - CGR (2009). Informe sobre los resultados del estudio de una muestra de las contrataciones efectuadas con los fondos no reembolsables suministrados por el BCIE al Gobierno de Costa Rica. Informe n. ${ }^{\circ}$ DFOE-SOC-11-2009 del 10 de febrero de 2009.

Cordero, M. (1986). La Cooperación Internacional en Ciencia y Tecnología. Sistema de las Naciones Unidas y otros organismos. Tesis para optar por el grado de Licenciado en Relaciones Internacionales. Escuela de Relaciones Internacionales, Universidad Nacional, Heredia, Costa Rica.

Gallardo, R. (2008, 16 de julio). Consultorías, salarios del Estado y fondos públicos. Sección Página Quince, La Nación, p. $31 \mathrm{~A}$.

Gallardo, R. (2008, 24 de julio). Mejor un debate informado. Sección Foro, La Nación, p. 31A.

González, A. (2008, 27 de agosto). El circo del BCIE. Sección Página Quince, La Nación, p. 37A.

Guardia, J. (2008, 8 de julio). Columna En Guardia. Sección Página Quince, La Nación, p. 37A.

Guardia, J. (2008, 22 de julio). Columna En Guardia. Sección Página Quince, La Nación, p. 37A.

Guardia, J. (2008, 29 de julio). Columna En Guardia. Sección Página Quince, La Nación, p. 29A.
Hernández, R. (2008, 21 de agosto). Un dictamen acertado. Sección Página Quince, La Nación, p. 31A.

La Nación (2008, 6 de julio). Eficacia y transparencia. Editorial, p. 28A.

La Nación (2008, 24 de octubre). Sé que no todo fue perfecto. Entrevista al señor Rodrigo Arias Sánchez, Ministro de la Presidencia. Sección El País, p. 5A.

Lahera, E. (2002). Introducción a las Políticas Públicas. Fondo de Cultura Económica. Chile, primera reimpresión.

Masís, F. (1988). La Cooperación Financiera Internacional y el Desarrollo Eléctrico de Costa Rica. Tesis para optar por el grado de Licenciada en Relaciones Internacionales. Escuela de Relaciones Internacionales, Universidad Nacional, Heredia, Costa Rica.

MIDEPLAN (2007a). Diagnóstico de la Cooperación Internacional en Costa Rica 2000-2005. San José, Costa Rica. 121 p. Recuperado el 15 de marzo de 2009 de: http:// www.mideplan.go.cr/content/view/56/462/

MIDEPLAN (2007b). Marco jurídico de la Cooperación Internacional en Costa Rica. Área de Cooperación Internacional, San José, Costa Rica. 13 p. Recuperado el 15 de marzo de 2009 de: http://www.mideplan.go.cr/content/view/62/467/

MIDEPLAN (2007c). Fortalecimiento de las Capacidades Institucionales para la Gestión de la Cooperación Internacional en Costa Rica 2007-2010. San José, Costa Rica. Recuperado el 15 de marzo de 2009 de: http://www. mideplan.go.cr/content/view/57/463/

Procuraduría General de la República - PGR (2000). Dictamen n. ${ }^{\circ}$ C-246-2000 del 4 de octubre de 2000. Recuperado el 31 de marzo de 2009 de: http://www.pgr. go.cr/scij/busqueda/normativa/pronunciamiento/ pro_repartidor.asp?param 1=PRD\&param6=1\&nDicta men=8845\&strTipM $=T$

Procuraduría General de la República - PGR (2003a). Dictamen . $^{\circ}$ C-125-2003 del 6 de mayo de 2003. Recuperado el 31 de marzo de 2009 de: http://www.pgr. go.cr/scij/Busqueda/Normativa/Pronunciamiento/ pro_repartidor.asp?param 1=PRD\&param6=1\&nDicta men=11814\&strTipM=T

Procuraduría General de la República - PGR (2003b). Opinión Jurídica n. ${ }^{\circ}$ OJ-124-2003 del 30 de julio del 2003. Recuperado el 31 de marzo de 2009 de: http://www. pgr.go.cr/scij/Busqueda/Normativa/Pronunciamiento/pro_repartidor.asp?param 1=PRD\&param6=1\&nDi ctamen $=11980 \&$ strTipM $=T$ 
Procuraduría General de la República - PGR (2004). Dictamen n. ${ }^{\circ}$ C-330-2004 del 12 de noviembre de 2004. Recuperado el 31 de marzo de 2009 de: http://www. pgr.go.cr/scij/Busqueda/Normativa/Pronunciamiento/pro_repartidor.asp? param 1=PRD\&param6=1\&nDi ctamen $=12821 \&$ strTipM $=$ T

Procuraduría General de la República - PGR (2008a). Opinión Jurídica n. ${ }^{\circ}$ OJ-067-2008 del 8 de agosto de 2008. Recuperado el 18 de marzo de 2009 de: http://www. pgr.go.cr/scij/Busqueda/Normativa/Pronunciamiento/pro_repartidor.asp?param 1=PRD\&param6=1\&nDi ctamen=15356\&strTipM $=T$

Procuraduría General de la República - PGR (2008b). Opinión Jurídica n. ${ }^{\circ}$ OJ-108-2008 del 27 de octubre de 2008. Recuperado el 18 de marzo de 2009 de: http:// www.pgr.go.cr/scij/Busqueda/Normativa/Pronunciamiento/pro_repartidor.asp?param 1=PRD\&param6=1 \&nDictamen=15559\&strTipM=T

Radio Universidad (2008, 30 de julio). Entrevista a los señores Jorge Mora Alfaro, Director de FLACSO - Costa Rica y Gerardo Riba Bazo, abogado litigante, efectuada por los señores Manuel Rojas Bolaños y Ana Elena Badilla en la primera edición del programa Desayunos de Radio Universidad.
Ramírez, J. \& Sánchez, R. (1995). La cooperación internacional en la coyuntura de la política exterior de la administración Arias Sánchez 1986-1990. Tesis para optar por el grado de Licenciados en Relaciones Internacionales. Escuela de Relaciones Internacionales, Universidad Nacional, Heredia, Costa Rica.

Rojas, E. (2008, 26 de julio). Comentarios en primera edición del programa Tiempos de Cambio. Radio Columbia.

Sala Constitucional de la Corte Suprema de Justicia (1990). Voto n. ${ }^{\circ} 1027-90$ de las 17:30 hrs. de 29 de agosto de 1990. Recuperado el 31 de marzo de 2009 de: http://200.91.68.20/scij/busqueda/jurisprudencia/ jur_repartidor.asp?param1=XYZ\&nValor1=1\&nValor2 $=82904 \&$ strTipM $=T$

Sobrado, M. (2008, 13 de julio). El frío no está en las cobijas. Sección de Opinión, La Nación, p. 24A.

Telenoticias (2008, 4 de julio). Entrevista al señor Rodrigo Arias Sánchez, Ministro de la Presidencia, efectuada por la señora Pilar Cisneros Gallo en la segunda edición del noticiario. 